\title{
Corporate Strategy and Performance of Kenyan Companies
}

\author{
Prof. Zachary Awino, PhD \\ Asoociate Professor, School of Business, \\ University of Nairobi \\ Dr. Bruce J Ogaga \\ School of Business, University of Nairobi \\ Dr. Vincent Machuki \\ PhD Senior Lecturer School of Business, \\ University of Nairobi
}

\begin{abstract}
The study examines the effect of corporate strategy on organizational performance. A structured questionnaire was used to collect data from 46 companies listed on the Nairobi Securities Exchange. Descriptive and inferential statistics were used to analyze the data. The study findings reveal that corporate strategy has significant effect on organizational performance. A theoretical and empirical implication of the study illustrate that the stakeholder theory is fully supported. Methodological implication shows that the validity and reliability tests carried out on the data collection instruments confirm that the instrument is sufficient to collect data from respondents. The researchers recommend future research on the individual corporate strategy constructs tested against the raw score of each of the seven performance indicators of Kenya's publicly quoted companies.
\end{abstract}

Key Words: Corporate Strategy, Organizational Performance, Stake-holders

\section{INTRODUCTION}

In the wake of myriad challenges and turbulence in the global market environment, the concept of corporate strategy has been embraced worldwide because of its perceived contribution to organizational performance. Researchers have postulated many factors that affect performance of companies globally, key among them is strategy. Aosa (1992) noted that emphasis in strategic management is mainly market driven approaches strategy, which should ideally help companies to gain sustainable competitive edge in the turbulent global market arena. Corporate strategy entails environmental scanning, strategy formulation, strategy implementation, and evaluation and control. Studies on strategy have indicated that firm competitive advantage could be generated from internal structure and resources through value creation in a manner that is rare and difficult to imitate (Busienei, 2013; Pfeiffer, 2013). Successful application of strategy contributes immensely to high firm performance (Ansoff, 1979). The choice to conduct this study was motivated by the fact that performance of most publicly quoted Kenyan companies has been dismal to the extent that some have lately called for financial bailout. Over the past few decades a lot of changes have taken place in Kenya and the global market arena. The country was affected by such international phenomena as globalization, recession fluctuation in oil prices, climate change and terrorism. Many listed companies in Kenya have gradually embraced corporate strategy as a fundamental tool in managing their processes. There is empirical evidence that joint effect of core competencies, core capabilities, strategy and strategy implementation lead to superior performance (Aosa, 2011; Awino, 2011). This study focused on companies listed on the Nairobi Securities 
Exchange, primarily because the Nairobi Securities Exchange is representative of the main sectors of the Kenyan economy.

\section{LITERATURE REVIEW}

The primary goal of strategy is to guide the organization in setting out its objectives, priorities, and refocuses itself towards realizing the same with a view to achieving superior performance. Empirical studies point out that a range of potential benefits to intrinsic values accrues to both the company and external stakeholders from the use of strategy. It is very useful to organizations during turbulent times (Ansoff et al., 1991). The strategic management process is fundamental in turning an organization's vision or mission into concrete achievable goals and objectives.

Handerson (1979) posits that the aim of strategy is to provide organizations with direction through a meticulously developed plan and a series of related opportunities which the organization follows. Advantages of formulating, developing and implementing strategy are manifold as it enables an organization to make the best use of its resources and opportunities in achieving its attendant objectives namely: It involves the whole organization and provides focus and review for managers and employees at all levels of the organization. It focuses on the relationship between the organization and its environment. It includes the management and leadership of both internal and external stakeholders. It covers the full range of activities the organization undertakes including products, services, competition, market and environmental changes. It is central to the creation of competitive advantage through added value and reduced costs. Additionally, Strategy helps organizations to focus on how they may create sustainable competitive advantage as a maximum objective or survive as a minimum in declining market situation (Porter, 1980).

Subsequently, companies seek to beat their competitors on cost leadership seek to add more value through differentiation for the same cost than competitors are able to do. However, the added value has to be perceived as such in the eyes of the paying customers or a particular market niche. The strategic approach was revived by Porter (1987) who did admit that strategy had fallen out of fashion in the 1970s but needed rediscovery and recasting to meet today's environmental demands (Aosa, 2011).This proposition is anchored on the organization, strategy, performance and environment (SOEP) dependent paradigm, which postulates that organizations must formulate appropriate strategies which align them to the external environment to enable them to attain superior performance (Ansoff, 1991; Ombaka,2014). Strategy is therefore, likely to give positive influence with respect to profitability and performance of the large firms.

Corporate strategy may be defined as the pattern of major objectives, essential policies and plans for achieving the goals stated in such a way as to define what business the company is in or is to be in and the type of company it is or is it to be (Andrews, 1971). From this definition, it is imperative to have a focus on the firm, its industry positioning, the need for implementation and the attendant achievement of the objectives. Additionally, we take cognizance of the fact that the cardinal goal of every organization is to achieve superior performance and long term survival in the constantly changing volatile global business environment.

Porter (1985) defined the goal of strategy as the search and realization of a favourable competitive position in an industry as well as a firm's positioning and competition. According to Ansoff (1987), strategic management is a systematic approach to position and relate the firm to its environment in such a way which will assure its continued success and make it 
secure from contingent surprises. This definition underscores firm positioning in the environment devoid of surprises and need for enhanced performance; where the surprises are caused by industry competition.

Many scholars including Johnson and Scholes (1993), Waweru (2008) and Aosa (2011) have conceptualized that strategic management is largely concerned with deciding on the strategy and planning how that strategy will be actualized through strategic analysis, strategic choice and ultimately strategy implementation. These scholars are implicit about competition with respect to choice which is a factor where various options or strategies are competing for implementation and these choices emanate from environmental conditions.

On the other hand the researchers are explicit about the need for implementation. Strategic management is the set of decisions and actions that result in the formulation and implementation of plans designed to achieve a company's objectives (Pearce and Robinson, 2007). From the foregoing definitions it is explicit that competition is central factor in strategy. Certo and Peter (1995) view strategy as a continuous iterative cross functional process aimed at keeping an organization as a whole appropriately matched to its environment. Since competition is part of the environment this can be a call for being cognizant of and responsive to competitor moves. It also calls for the need for success in all environmental conditions. The authors further emphasize strategy implementation as an imperative for strategic management and organizational success.

Ansoff (1987) contends that strategy is an elusive and somewhat abstract concept. This concept may be crystallized by a definition of strategic management as a synergy of the various elements and procedures of strategy which culminate in a synthesized competitive strategy implementation aimed at achieving sustainable competitive advantage and superior performance. It is thus explicit that all endeavours in strategic management are geared towards attainment of competitive edge and ultimately superior firm performance and organizational success.

\section{METHODOLOGY}

The researcher used the deductive approach of positivism research philosophy. The research design was the cross sectional survey. The population of the study was all the companies listed on the Nairobi Securities Exchange. Reliability and validity test were conducted. The primary data was collected from the key managers using a structured questionnaire while the secondary data was obtained from the Nairobi Securities Exchange office. Data was analyzed using the multi-level analysis.

\section{Corporate Strategy and Performance}

The first objective of the study was to determine the effect of corporate strategy on organizational performance. Hypothesis $\left(\mathrm{H}_{1}\right)$ was stated as: Corporate strategy has significant effect on organizational performance. The study set out to establish the independent effect of corporate strategy on organizational performance. Corporate strategy was measured using generic strategies constructs namely: cost leadership, differentiation and focus together with strategic alliance construct.

This section summarizes the effects of corporate strategy on each operational indicator of organizational performance. The operational indicators of performance included earnings per share, internal business processes, customer perspective, learning and growth, employee perspective, market share, corporate social responsibility (CSR) and environmental 
responsiveness. At the end a regression test was run on the effects of corporate strategy on overall organizational performance. The section presents the tables and their interpretations. Test of hypothesis was done using three tables: model summary, analysis of variance (ANOVA), and coefficients. Table 4 presents the results of the test $p$-value of the influence of corporate strategy on earnings per share.

Table 4: Influence of Corporate Strategy on Earnings per Share

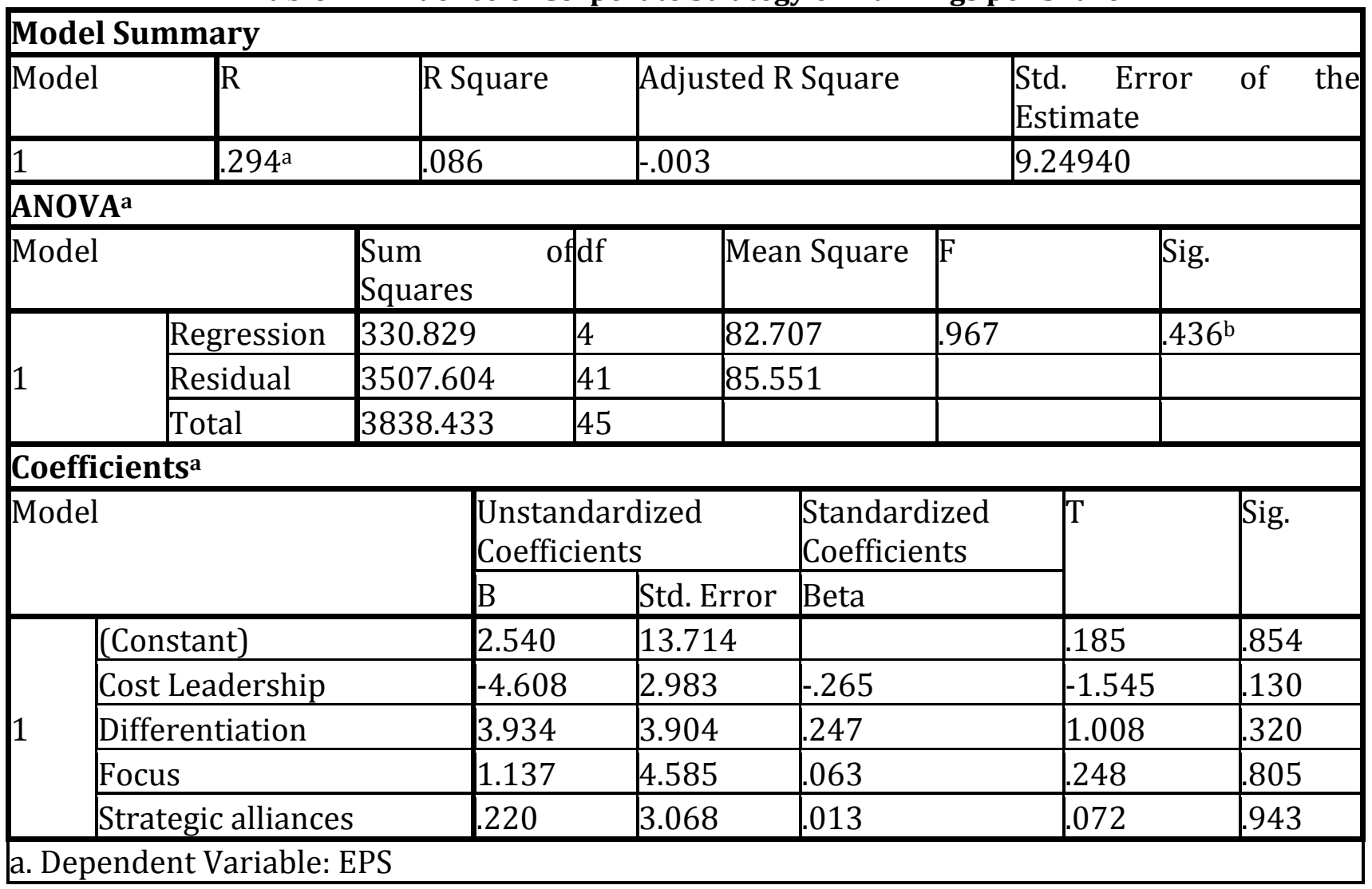

b. Predictors: (Constant), Strategic Alliances, Cost Leadership, Differentiation, Source: Research Data (2015)

Table 4 shows the results of the analysis done to establish the effect of corporate strategy on earnings per share. The results indicate that strategy is correlated with earnings per share up to $0.294(\mathrm{R}=0.294)$. Further, strategy explains 8.6 percent variations in earnings per share $\left(\mathrm{R}^{2}\right.$ $=0.086$ ) with the remaining 91.4 percent being explained by other variables which were not considered in this model. The $F$ value for the model was 0.967 and $p$-value was 0.436 . Since the calculated $p$-value was greater than 0.05 , the hypothesis was rejected implying that corporate strategy had no significant effect on Earnings per Share. Therefore, the model was not robust enough to predict the hypothesized relationship. To test the relationship between corporate strategy and internal business processes, a multivariate regression analysis was conducted. The results are presented in Table 5. 
Table 5: Influence of Corporate Strategy on Internal Processes



\section{Source: Research Data (2015)}

Table 5 shows the results of the analysis done to establish the effect of corporate strategy on internal processes. The results indicate that strategy is correlated with internal processes up to $0.858(\mathrm{R}=0.584)$. Further, strategy explains 73.6 percent variations in internal processes $\left(\mathrm{R}^{2}\right.$ $=0.736$ ) with the remaining 26.4 percent being explained by other variables which were not considered in this model. The $F$ value for the model was 28.634 and $p$-value was 0.00 . Since the calculated $p$-value was less than 0.05 , the study failed to reject the hypothesis implying that strategy had a significant effect on internal processes. Therefore, the model was robust enough to predict the hypothesized relationship. The analysis of t-test values showed significant results for the coefficients of cost leadership and environmental dependency. This relationship was presented in the following equation.

Internal Processes $=1.011+0.628$ cost leadership +0.299 strategic alliance .

The model shows that a unit change in cost leadership and strategic alliance will result in internal business processes changing by0.628 and 0.299 , respectively. To test the relationship between corporate strategy and internal business processes, a multivariate regression analysis was conducted. The results are presented in Table 6. 
Table 6: Influence of Corporate Strategy on Customer Perspective

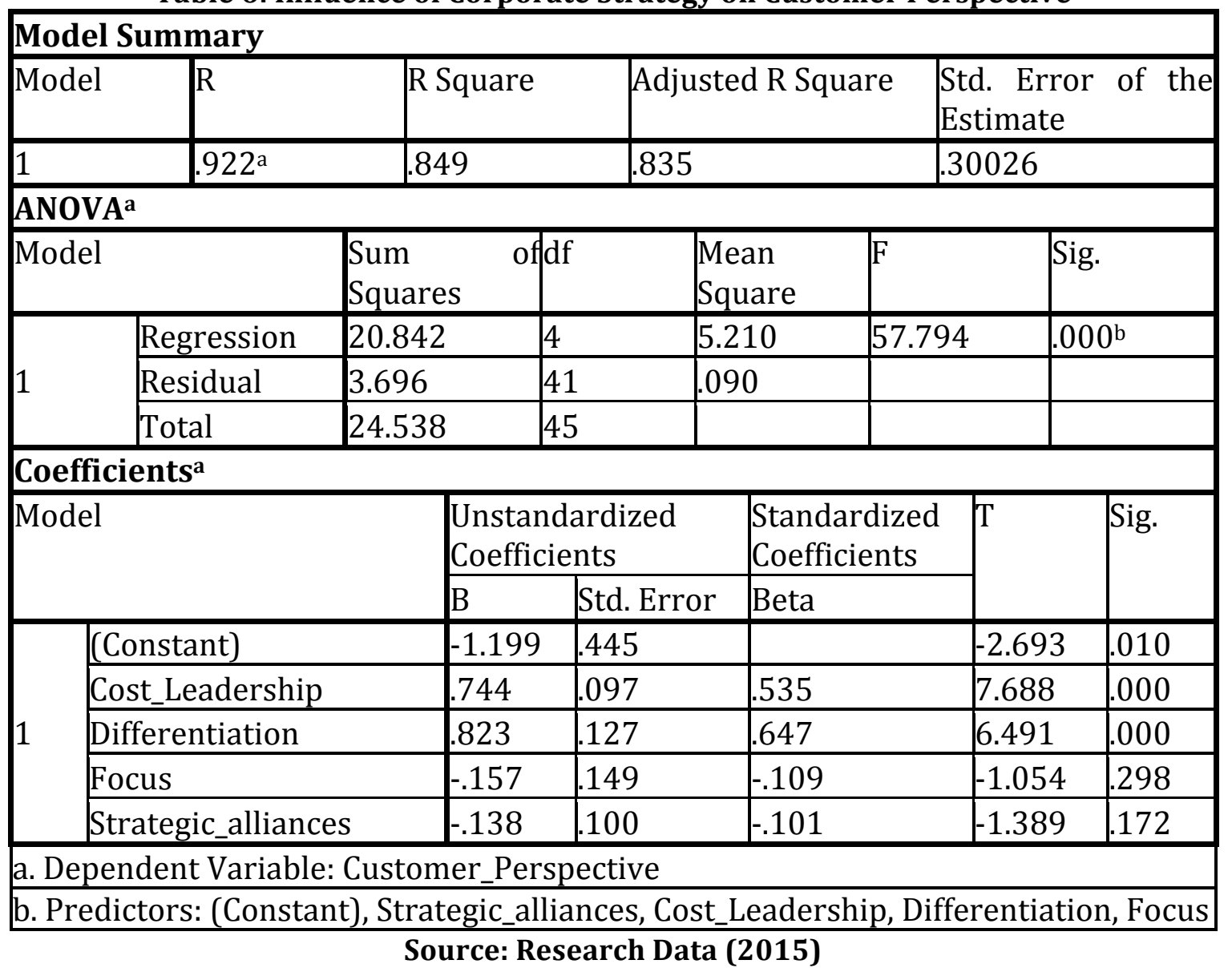

Table 6 shows the results of the analysis done to establish the effect of corporate strategy on customer perspective. The results indicate that corporate strategy is correlated with customer perspective up to $0.922(\mathrm{R}=0.922)$. Further, strategy explains 84.9 percent variations in customer perspective $\left(\mathrm{R}^{2}=0.849\right)$ with the remaining 15.1 percent being explained by other variables which were not considered in this model.

The $F$ value for the model was 57.794 and $p$-value was 0.00 . Since the calculated $p$-value was less than 0.05 , the study failed to reject the hypothesis implying that strategy had a significant effect on customer perspective. Therefore, the model was robust enough to predict the hypothesized relationship.

The analysis of t-test values showed significant results for the coefficients of cost leadership and differentiation. This relationship was presented in the following equation.

Customer Perspective $=1.199+0.744$ cost leadership +0.823 diffentiation

The model shows that a unit change in cost leadership and differentiation will result in customer perspective changing by0.744 and 0.823 , respectively. To test the relationship between strategy and employee perspective, a multivariate regression analysis was conducted. The results are presented in Table 7. 
Table 7: Corporate Strategy and Employee Perspective



\section{Source: Research Data (2015)}

Table 7 shows the results of the analysis done to establish the effect of strategy on employee perspective. The results indicate that strategy is correlated with employee perspective up to 0.915 ( $\mathrm{R}=0.915)$. Further, corporate strategy explains 83.8 percent variations in employee perspective $\left(\mathrm{R}^{2}=0.838\right)$ with the remaining 16.2 percent being explained by other variables which were not considered in this model. The $F$ value for the model was 52.976 and p-value was 0.00. Since the calculated p-value was less than 0.05 , the study failed to reject the hypothesis implying that strategy had a significant effect on employee perspective. Therefore, the model was robust enough to predict the hypothesized relationship. The analysis of t-test values showed significant results for the coefficients of differentiation and focus. This relationship was presented in the following equation.

\section{Employee Perspective $=0.643$ differentiation +0.491 focus}

The model shows that a unit change in differentiation and focus will result in employee perspective changing by 0.643 and 0.491 , respectively. Another operational indicator of performance is learning and growth. To test the relationship between strategy and learning and growth, a multivariate regression analysis was conducted. The results are presented in Table 8. 
Table 8: Corporate Strategy, Learning and Growth

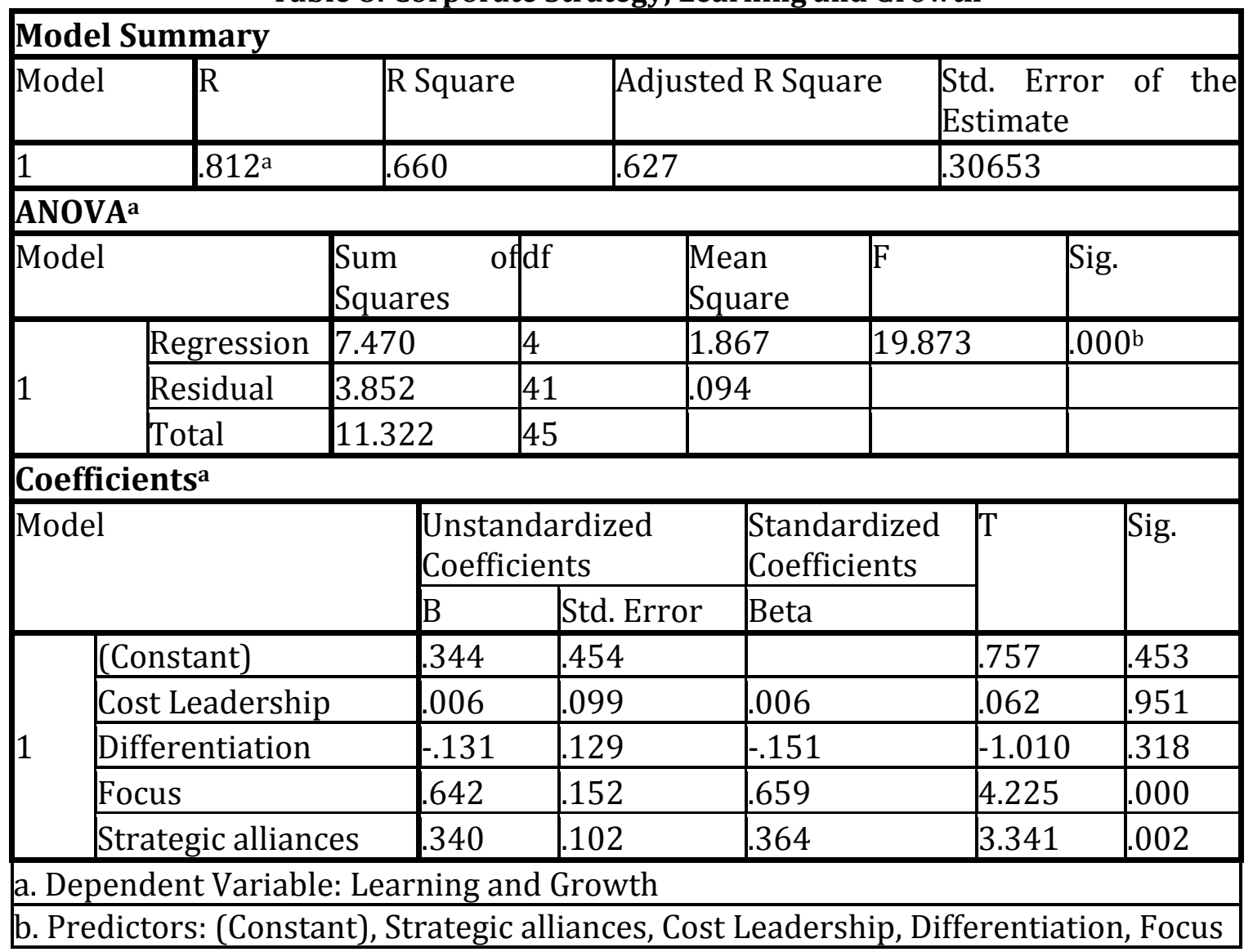

\section{Source: Research Data (2015)}

Table 8 shows the results of the analysis done to establish the effect of various indictors of strategy on learning and growth. The results indicate that strategy is correlated with learning and growth unto $0.812(\mathrm{R}=0.812)$. Further, corporate strategy explains 66 percent variations in learning and growth $\left(\mathrm{R}^{2}=0.660\right)$ with the remaining 34 percent being explained by other variables which were not considered in this relationship. The F value for the model was 19.873 and p-value was 0.00 . Since the calculated p-value was less than 0.05 , the study failed to reject the hypothesis implying that strategy had a significant effect on learning and growth. Therefore, the model was considered robust enough to predict the hypothesized relationship.

The analysis of t-test values showed significant results for the coefficients of focus and Strategic alliances. This relationship was presented in the following equation:

Learning and Growth $=0.642$ focus +0.340 Strategic alliances

The model shows that a unit change in focus and strategic alliance will result in learning and growth changing by 0.642 and 0.340 , respectively. Another operational indicator of performance is environmental perspective. To test the relationship between strategy and environmental perspective, a multivariate regression analysis was conducted. The results are presented in Table 9. 
Table 9: Corporate Strategy and Environmental Perspective

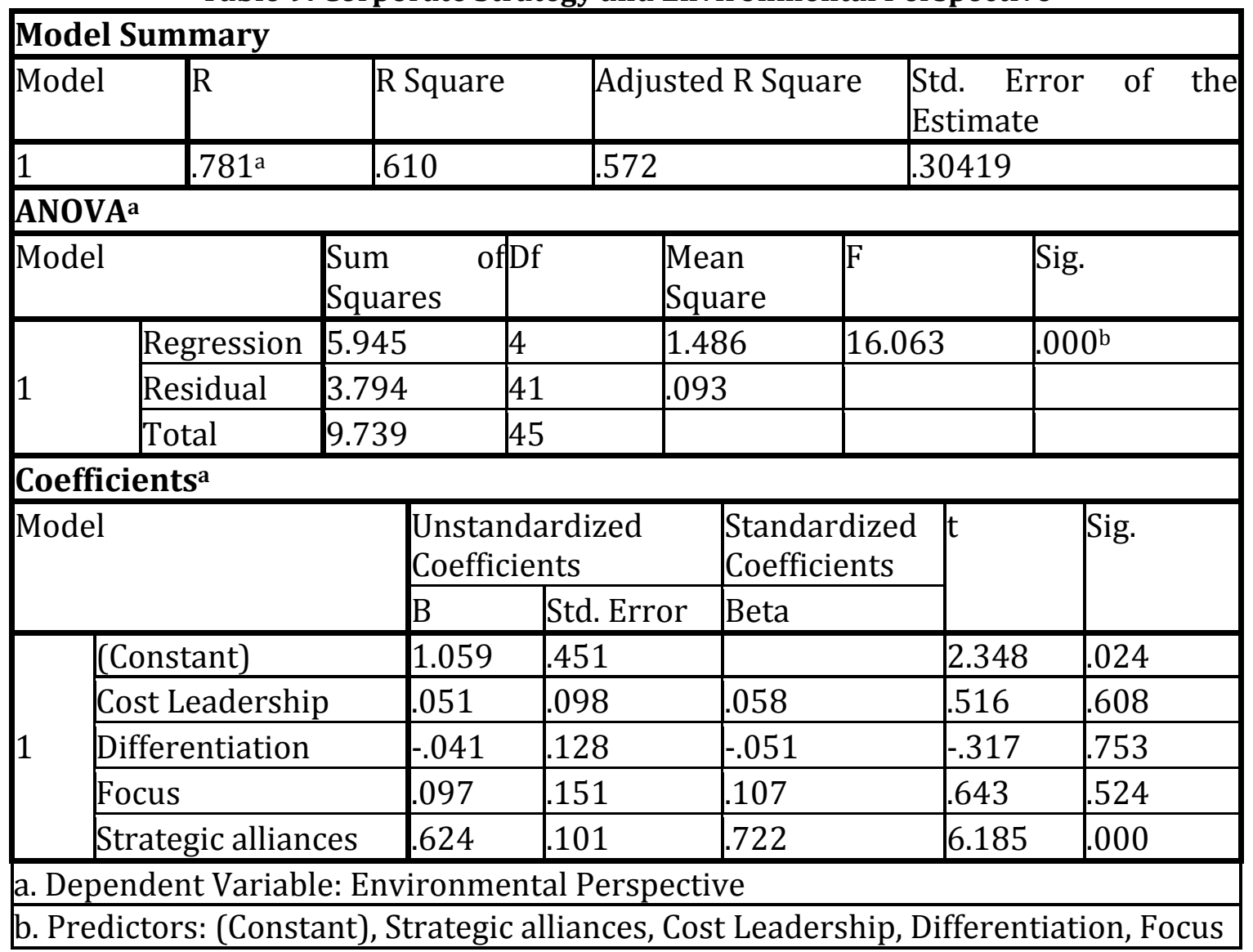

\section{Source: Research Data (2015)}

Table 9 shows the results of the analysis done to establish the effect of various indicators of strategy on environmental perspective. The results indicate that corporate strategy is correlated with environmental perspective up to $0.781(\mathrm{R}=0.781)$. Further, strategy explains 61 percent variations in learning and growth $\left(R^{2}=0.610\right)$ with the remaining 39 percent being explained by other variables which were not considered in this relationship.

The $\mathrm{F}$ value for the model was 16.063 and $\mathrm{p}$-value was 0.00 . Since the calculated $\mathrm{p}$-value was less than 0.05 , the study failed to reject the hypothesis implying that corporate strategy had a significant effect on environmental perspective. Therefore, the model was considered robust enough to predict the hypothesized relationship. The analysis of t-test values showed significant results for environmental dependency only. The reset of the coefficients were statistically not significant. This relationship was presented in the following equation:

Environmental perspective $=1.059+0.624 \mathrm{e}$ strategic alliance

The model shows that a unit change in strategic alliance will result in environmental perspective changing by0.624. Another operational indicator of performance considered for this study was corporate social responsibility. To test the relationship between strategy and corporate social responsibility, a multivariate regression analysis was carried out. The results are presented in Table 10. 
Table 10: Corporate Strategy and Corporate Social Responsibility

\begin{tabular}{|c|c|c|c|c|c|c|c|c|}
\hline \multicolumn{9}{|c|}{ Model Summary } \\
\hline \multirow[t]{2}{*}{ Model } & $\mathrm{R}$ & \multicolumn{2}{|c|}{ R Square } & \multicolumn{3}{|c|}{ Adjusted R Square } & \multicolumn{2}{|c|}{$\begin{array}{l}\text { Std. Error of the } \\
\text { Estimate }\end{array}$} \\
\hline & $612^{\mathrm{a}}$ & \multicolumn{2}{|c|}{.374} & \multicolumn{2}{|l|}{.313} & & \multicolumn{2}{|l|}{.33233} \\
\hline \multicolumn{9}{|c|}{ ANOVA $^{a}$} \\
\hline \multicolumn{2}{|l|}{ Model } & \multicolumn{2}{|c|}{$\begin{array}{l}\text { Sum } \\
\text { Squares }\end{array}$} & & $\begin{array}{l}\text { Mean } \\
\text { Square }\end{array}$ & $\mathrm{F}$ & \multicolumn{2}{|c|}{ Sig. } \\
\hline \multirow{3}{*}{1} & Regression & \multicolumn{2}{|l|}{2.711} & & .678 & \multicolumn{2}{|c|}{6.136} & $.001^{\mathrm{b}}$ \\
\hline & Residual & \multicolumn{2}{|l|}{4.528} & 1 & 110 & \multirow{2}{*}{\multicolumn{2}{|c|}{ 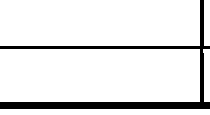 }} & \\
\hline & Total & \multicolumn{2}{|l|}{7.239} & 45 & & & & \\
\hline \multicolumn{9}{|c|}{ Coefficients $^{\mathrm{a}}$} \\
\hline \multirow{2}{*}{\multicolumn{2}{|c|}{ Model }} & & \multicolumn{2}{|c|}{\begin{tabular}{|l|} 
Unstandardized \\
Coefficients
\end{tabular}} & \multirow{2}{*}{\multicolumn{2}{|c|}{\begin{tabular}{|l|}
$\begin{array}{l}\text { Standardized } \\
\text { Coefficients }\end{array}$ \\
Beta
\end{tabular}}} & \multirow[t]{2}{*}{$T$} & \multirow[t]{2}{*}{ Sig. } \\
\hline & & & $\mathrm{B}$ & Std. Error & & & & \\
\hline \multirow{5}{*}{\begin{tabular}{|l}
$\mathrm{CC}$ \\
$\mathrm{C}$ \\
$\mathrm{D}$ \\
$\mathrm{F}$ \\
$\mathrm{St}$ \\
\end{tabular}} & Constant) & & 1.691 & 493 & & & 3.432 & .001 \\
\hline & st Leadership & & .275 & 107 & 364 & & 2.569 & .014 \\
\hline & fferentiation & & .207 & 140 & 300 & & 1.478 & 147 \\
\hline & cus & & .060 & .165 & .077 & & .366 & .716 \\
\hline & rategic alliances & & -.023 & 110 & -.031 & & -.209 & .836 \\
\hline
\end{tabular}

Source: Research Data (2015)

Table 10 presents the results of the analysis done to establish the effect of various indicators of strategy on corporate social responsibility. The results indicate that corporate strategy is correlated with corporate social responsibility up to $0.612(\mathrm{R}=0.612)$. Further, strategy explains 37.4 percent variations in corporate social responsibility $\left(\mathrm{R}^{2}=0.374\right)$ with the remaining 62.6 percent being explained by other variables which were not considered in this relationship. The F value for the model was 6.136 and $p$-value was 0.001 . Since the calculated $p$-value was less than 0.05 , the study failed to reject the hypothesis implying that strategy had a significant effect on corporate social responsibility. Therefore, the model was considered robust enough to predict the hypothesized relationship. This relationship was represented in the following equation:

Corporate social responsibility $=1.691+0.275$ cost leadership +0.207 diffrentiation +0.06 Focus - 0.023 strategic alliance

However, the analysis of $t$-test values showed significant results for the constant and cost leadership only. The rest of the coefficients were statistically not significant. The resultant equation was thus written as:

\section{Corporate social responsibility $=1.691+0.275$ cost leadership}

The model shows that a unit change in cost leadership will result in corporate social responsibility changing by 0.275 . Finally, to test the main hypothesis, a composite score for performance was developed. The composite was drawn from all the seven indicators of performance considered in this study. To test the relationship between strategy and overall 
performance, a multivariate regression analysis was carried out. The results are presented in Table 11.

Table 11: Corporate Strategy and Overall Performance

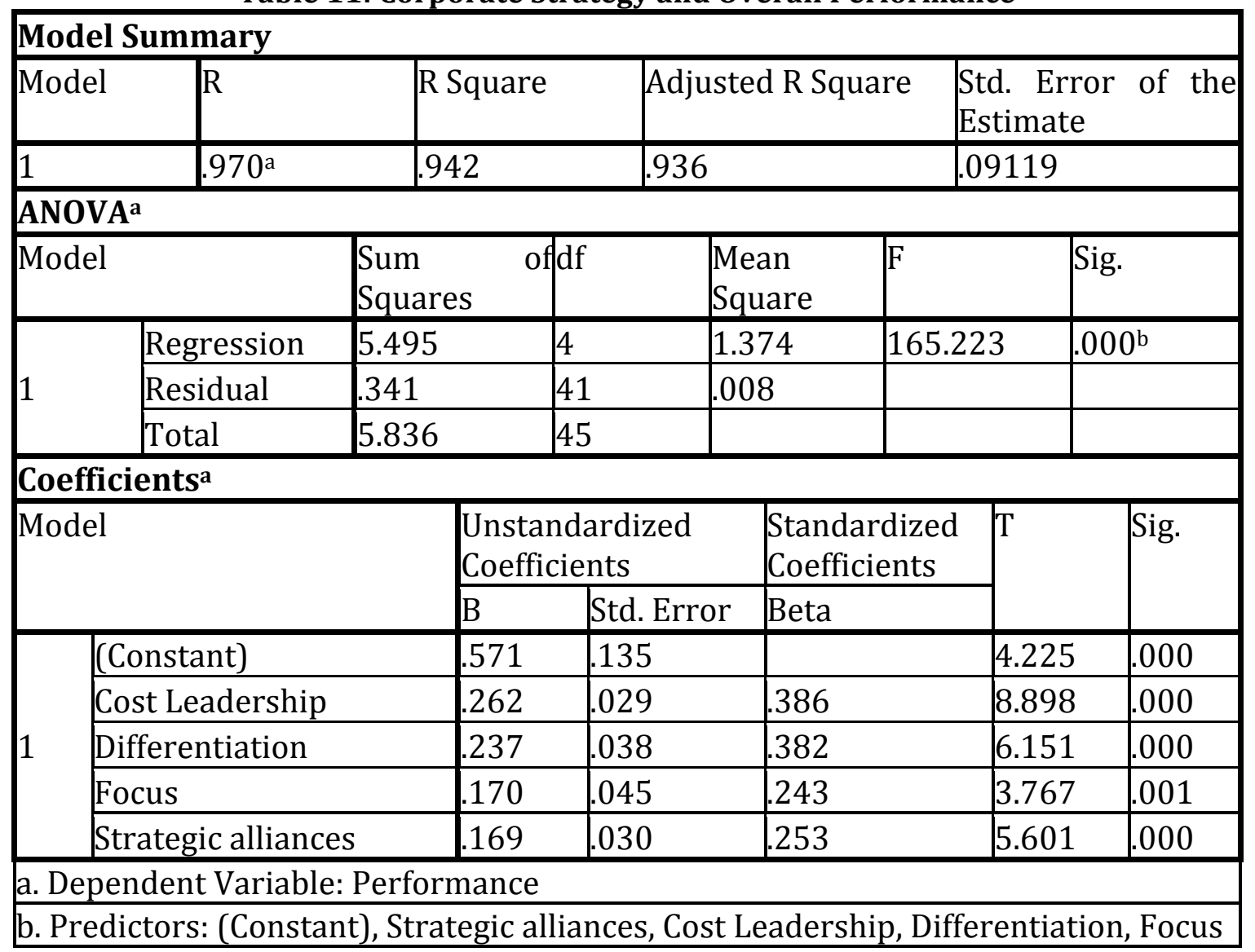

Source: Research Data (2015)

Table 11 presents the results of the analysis done to establish the effect of various indicators of strategy on performance. The results indicate that corporate strategy is correlated with environmental perspective up to $0.971(\mathrm{R}=0.971)$. Further, corporate strategy explains 94.7 percent variations in learning and growth $\left(\mathrm{R}^{2}=0.94 .7\right)$ with the remaining 5.3 percent being explained by other variables which were not considered in this relationship. Overall, there was a very strong fit $\left(\mathrm{R}^{2}=0.942\right)$ whereby all the indicators contributed positively and were hence statistically significant. The $\mathrm{F}$ value for the model was 165.223 and $p$-value was 0.00 . Since the calculated $p$-value was less than 0.05 , the study failed to reject the hypothesis implying that corporate strategy had a significant effect on performance. Therefore, the model was considered robust enough to predict the hypothesized relationship. The analysis of $t$-test values showed significant results for all the indicators of strategy. This relationship was presented in the following equation:

Performance $=0.571+0.262$ cost leadership +0.237 differentiation +0.170 focus +0.169169 strategic alliances

The model shows that a unit change in cost leadership, differentiation, focus and strategic alliance will result in performance changing positively by0. 262,0.237, 0.170 and 0.169 , respectively.

\section{DISCUSSION}

The first objective of this study was to establish the effect of strategy on organizational performance. The findings of the study revealed that strategy was present to a large extent 
within the companies listed on the NSE. These findings were in tandem with Aosa (2011) who established that Kenyan firms had indeed adopted strategy as a fundamental management tool. Presence of strategy in organizations has been postulated to have positive effect on performance on organizational performance.

The study findings were also in agreement with Arasa and K'Obonyo (2012) who established that strategy was positively related to performance. However, this study contradicted the findings of Machuki and K'Obonyo (2011) who investigated the same context as this study. In their study, they established that corporate strategy influence on firm performance was not statistically significant. Furthermore, their study established that strategic alliance had a negative influence on organizational performance. On the contrary the current study found that strategy had a statistically significant influence on firm performance. The study also found out that strategic alliance had positive impact on firm performance.

Awino (2011) established that 34.4 per cent variation in corporate performance is explained by strategy. This study explained that 94.2 per cent influence organizational performance. Good corporate strategy was found to have a positive relationship and impact on firm performance. These results concurred with those of Wallin and Lindastad (1998) who established the same in Norwegian companies. They established that a good strategy that has customer in mind directly leads to greater customer loyalty.

Additionally the study was in tandem with propositions of Payne and Frow (2005) which state that for exceptional customer value as well as shareholder value, corporate strategy is important. The study further supported the propositions of Kaplan and Norton (1992) that customer value proposition should be the basis of corporate strategy

\section{CONCLUSION}

It was established that the influence of corporate strategy on firm performance was statistically significant. The study also reported statistically significant independent effects of the four corporate strategy dimensions:

Porter's (1980) generic strategies namely cost leadership, differentiation and focus together with strategic alliances on some indicators of performance. It can thus be concluded that corporate strategy has an influence on organizational performance. The results support the dynamic capabilities theory, resource based view and industrial organization (IO) economics theory (Bain, 1956, Mason 1939), the S-C-P paradigm, game theory, contingency theory and stakeholder theory (Morton \& Hu, 2008. The study further noted some key relationships and variations between the publicly quoted companies' performance and corporate strategy.

\section{IMPLICATION OF THE STUDY}

Corporate strategy was the independent and firm performance was the dependent variable. The findings of the study have multifaceted implications to various stakeholders. The outcomes provide rich implications to scholars, practitioners and policy makers.

This study has advanced frontiers of knowledge from the study findings. It lends support for the relationship between corporate strategy and organizational performance (Porter, 1996; Barney 1997; Owino, 2014). The result contributes to the strengthening of the literature by confirming the postulations of stake holders theory and theory of congruence (Upadhayay et al, 2013). 
The results of the study show that corporate strategy has a strong positive influence on organizational performance. Policy can be developed to encourage measurement and reporting of performance along the indicators of the SBSC as used in this study (Kaplan \& Norton, 1992; Elkington, 1997).

The results from this study provide several implications on methodology. Validity and reliability tests were carried out on the data collection instrument and it was found that the instrument was sufficient to collect data from the respondents. Given that the tests were positive, it is an indication that the data collected was reliable and future research may consider using the same methods for data collection. A drop and pick method was used to get the questionnaire to the respondents and getting them back. The sampling method used in the study was also important. The use of regression made it very easy to test the hypotheses that were developed to achieve the research objectives.

\section{Managerial Implication}

The study has immense implication on managerial practice particularly with respect to strategic decision making and scope of operation. First, it has implication in terms of cost management, product quality and development, internal processes, employee and customer satisfaction. The managerial practices of most companies reveal that generic strategies are applied on customer satisfaction mostly by companies whose strategic stances are prospectors and reactors and adopted the strategies of market penetration, diversification and differentiation as modes of strategic alliance (Ogendo, 2014). Moreover, internalization is applied on internal business process on licensing strategies. The study found out that corporate strategy had significant effect on all nonfinancial performance indicators, but had no statistically significant effect on financial indicator, EPS. It is therefore poised to help organizations top management teams make strategic decision on matters pertaining to choice of the right technology, innovation, recruitment of employee and skills development.

\section{ACKNOWLEDGEMENT}

I acknowledge my supervisors, Prof. Z.B. Awino for his erudite organizational and strategic skills, Dr. V.N. Machuki for his oratory skills and outstanding mastery of strategic concepts, and Prof. G. P. Pokhariyal for his enormous mathematical and statistical knowledge. Dons, I profusely thank you for your profound, in depth and robust guidance throughout the PhD. Program.

\section{Reference}

Andrews, K.R. (1971). The Concept of Strategy (New York: Dow Jones-Irwin,1971).

Ansoff, H. I. (1991). Critique of Henry Mintzberg's. The design school: Reconsidering the basic Premises of the Strategic Management. Strategic Management Journal, 12(6), 449-461.

Aosa, E. (1992).An Empirical Investigation of Aspects of Strategy Formulation and Implementation within Large Private Manufacturing Firms in Kenya. Unpublished PhD. Thesis, University of Strathchlyde, Glasgow, Scotland.

Aosa, E. (2011). Strategic Management within Kenya Firms. DBA Africa Management Review, 1(1), 25-36.

Arasa, R. \& K'Obonyo, P. (2012).The Relationship between Strategic Planning and Firm Performance. International Journal of Humanities and Social Science,2(2)

Awino, Z.B. (2011). An Empirical Investigation of selected strategy variables on firms Performance: A Study of supply chain management in Large Private Manufacturing Firms in Kenya. Prime Journals, 1(1), 9-18.

Bourgeois, L.J.III (1980). Strategy and Environment: A Conceptual Integration. Academy of Management Review, 5(1), 25-39.

Brunk, K.H. \& Blumelhuber, C. (2011). Quantitative Insights into the formation of consumer's company or brand perceptions, Journal of Business Research, 64 (2), 134-141. 
Busienei, J. R. (2013).Business Strategy, Organizational Structure, Human Resource Orientation of Large Manufacturing Firms in Kenya. Unpublished Ph.D. Thesis. University of Nairobi.

Certo, S.C. \& Peter, P.J. (1995). The Strategic Management Process. Chicago, Irwin.

Chakravarthy, B.S. (1997). A new strategy framework for coping with turbulence. Sloan Management Review, Winter, 69-82.

Chen, M.J. (2010). What is Strategic Management? Darden Business Publishing, University of Virginia.

Collins, D. J. \& Rukstand, M. G. (2013). Can you say what you strategy is? Havard business Review on point, 28-30.

Combs, J.G., Crook, R.T., \& Shook, C. L. (2005).The dimensionality of organizational performance and its implications for strategic management research. Research Methodology in Strategy and Management, 2, 259-286

Daft, R.L. (2013). Organization Theory and Design, 11 thed.Cincinati: Cencage.

David, F.R. (1997).Strategic Management. New Jersey, Prentice Hall.

Drucker, P. (1954). The practice of management. New York: Harper and Brothers

Elkingtons J. (1997). Cannibals with Porks; The Triple Bottom Line of the $21^{\text {st }}$ Century Business. Gabtiole Island: Capstone.

Grant, R.M. (2013). Contemporary Strategy Analysis John Wiley\& Sons Ltd. W. Sussex, U.K.

Handerson, B.D. (1979). Understanding Corporate Strategy. Prentice Hall.


Hall.

Hubbard, G. (2009). Measuring Organizational Performance Beyond Triple Bottom Line. Business Strategy and Environment, 19, 177-191.

Ireland, R. D., Hoskisson R. E. \& Hit, M.A. (2013).The Management of Strategy Concepts and Cases. South Western, Cengage Learning, Canada.

Johnson, G. \& Scholes, K. (1999). Exploring Corporate Strategy. 7th Edition, Hertfordshire, Prentice Hall.

Johnson, G., Scholes, K. \& Whittington, R. (2008).Exploring Corporate Strategy. Prentice Hall.

Kaplan, R.S. \& Norton, D.P. (1992). The balanced scorecard: Measures that Drive performance. Harvard Business Review, 70(1), 71-79.

Kinuu, D. (2014). Top Management Team Psychological Characteristics, Institutional Environment, Team Process and Performance of Companies Listed in Nairobi Securities Exchange. Unpublished PhD. Thesis. University of Nairobi.

Kotter, J. P. (1996). Leading Change. Boston Massachusetts, Harvard Business School Press.

Machuki, V.N. \& K'Obonyo, P.O. (2011). Organizational Strategic Behaviour and Performance of Publicly Quoted companies in Kenya. Prime Journals: Business Administration and Management, 1(7) 219-232.

Machuki, V.N. \& Aosa, E. (2011). The Influence of External Environment on the Performance of publicly quoted companies in Kenya: Administration and Management Journal, 1 (7), 205-218.

Machuki, V.N. (2011). External Environment Strategy Co-alignment firm level institutions and performance of publicity quoted companies in Kenya. Unpublished PhD. Thesis, University of Nairobi.

Miles, R. E. \& Snow, C. C. (1986). Organizational Strategy, Structure, and Process. New York, McGraw-Hill.

Mintzberg, H. (1983). Structures in Firms: Designing Effective Organizations. Englewood Cliffs, NJ: Prentice Hall.

Mintzberg H., Alstrand B., \& Lampel J. (1998). Strategy Safari: A Guided Tour through Wilds of Strategic Management. The Free Place New York, NY 10020.

Mintzberg, H. (2003).The Strategy Concept. The Strategy Concept: Five Ps for Strategy. California Management Review, 30(1).11-24.

Mkalama, R.N. (2014). Top Management Demographics, Strategic Decision Making, Macro-environment and Performance of Kenyan State Corporations. Unpublished PhD. Thesis, University of Nairobi.

Ombaka, B.E. (2014). Resources, External Environment, Innovation and Performance of Insurance Companies in Kenya. Unpublished PhD Thesis. University of Nairobi. 
Ongeti, W.J. (2014).Organizational Resources, Corporate Governance Structures and Performance of Kenyan State Corporations. Unpublished PhD Thesis. University of Nairobi.

Nickell, S.J. (1996). Competition and Corporate Performance, Journal of political Economy, 104 (4), $724-746$.

Parnell, J.A. (2013). Uncertainty, Generic Strategy, Strategic Clarity and Performance of Retail SME in Peru, Argentina, and the United States.

Pearce, J.A. \& Robinson, R.B. (2007). The Five Competitive forces that shape Strategy. Harvard Business Review, January.

Pfeffer.J. (2013). Power, Capriciousness and Consequences. Harvard Business Review, June, 21-30.

Porter, M. E. (1980). Competitive Strategy: Techniques for Analyzing Industries and Competitors. New York, Free press.

Porter, M. E. (1985). Competitive Advantage: Creating and Sustaining Superior Performance. New York: Free Press

Porter, M. E. (1987). Corporate Strategy: The State of Strategic Thinking. The Economist. 303 (7499). 21-28.

Porter, M.E. (1996). What is Strategy? Harvard Business Review August - September, 58-79.

Schendel, D.E. Hofer, C.W. (1979). Research Needs and Issues in Strategic Management.

Stoner, C.R. (1983), Planning in Small Manufacturing Firms. Journal of Small Business Management, 1, 34-40.

Venkatraman, N. \& Ramanujam, V. (1986). Measurement of business performance in strategy research: A Comparison of approaches. The Academy of Management Review, 11(4), 801-814.

Waweru, M.A. (2008). Competitive Strategy Implementation and its effect on large Private sector firms in Kenya. Unpublished PhD Thesis. University of Nairobi.

Weiss, A. R. \& Birnbaum, P.H. (1989). Technological infrastructure and the implementation of technological strategies. Management Science, 35 (8), 1014-1026. 